\title{
AKAR-AKAR SOSIOLOGIS PEMIKIRAN HUKUM ISLAM ABU HANIFAH
}

\author{
Fahmi Assulthoni \\ STAI Miftahul Ulum Pamekasan \\ Email:soulelousa@gmail.com \\ Moh. Safik \\ STAI Miftahul Ulum Pamekasan \\ Email: syafhickzalbazanjary@yahoo.co.id
}

\begin{abstract}
Abu Hanifah as one of the grand fuqaha who is believed to think in the world at the time, now even for an unlimited time is interesting to read. His thoughts are tinkering with the rational logic of Muslim thinkers after competing to find out the basic laws that affect his mindset. Abu Hanifa was the only fiqh scholar who put forward his mind on a problem that was not found in the Qur'an or hadith seen by the Prophet Muhammad. If explored further, it will be known factors that influence the mindset, as well as what is taken into account are social factors. Social factors in this paper such as community factors when Abu Hanifah lived, intellectual factors, professional factors, political dynamics that occur and others. This commentary is important so that the next generation of Muslims knows about the establishment of Islamic law not only having one dimension, but many dimensions that influence it. Abu Hanifah from several existing literature. From this normative study, conclusions from sociological roots that debate the law of Abu Hanifah are needed by several factors, namely geographical-sociological factors, intellectual factors, professional factors, political factors and renewed personal support.
\end{abstract}

Keywords: sociological roots, thought, Abu Hanifah

\section{Pendahuluan}

Memasuki abad ke-2 Hijriah dalam kalender Islam menjadi era kelahiran mazhab-mazhab hukum. Dua abad kemudian mazhab-mazhab hukum ini telah melembaga dalam masyarakat Islam dengan pola dan karakteristik tersendiri dalam melakukan istinbat $\}$ (penetapan) hukum. Para tokoh atau imam mazhab seperti Abu Hanifah, Imam Malik, Imam Shafi'i, Ahmad bin Hanbal dan lainnya, masing-masing menawarkan kerangka metodologi, teori dan kaidahkaidah ijtihad yang menjadi pijakan mereka dalam menetapkan hukum.

Metodologi, teori dan kaidah-kaidah yang dirumuskan oleh para tokoh dan para Imam mazhab ini, bertujuan untuk memberikan jalan dan merupakan Ulumuna: Jurnal Studi Keislaman

Vol.5 No.2 Desember 2019:

P-ISSN 2442-8566

E-ISSN 2685-9181 
langkah-langkah atau upaya dalam memecahkan berbagai persoalan hukum yang dihadapi. Baik dalam memahami nas al-Qur'an dan al-Hadis maupun kasuskasus hukum yang tidak ditemukan jawabannya dalam nas.

Salah seorang imam mujtahid yang dianggap berangkat dari latar belakang abl al-ra'yi ialah Abu Hanifah. Abu Hanifah merupakan seorang ulama yang sangat hati-hati dalam menyeleksi hadis dan banyak menetapkan hukum dengan logika. Namun dari beberapa sumber hukum menurutnya, istib $\}$ san merupakan metode ijtihad yang paling menonjol. Hal ini sangatlah wajar terjadi kepada setiap mujtahid, karena banyak faktor yang mempengaruhi alam pemikirannya. Dari uraian singkat di atas dapat dilihat bahwa penulis dalam tulisan ini mencoba untuk menganalisis pemikiran Imam Abu Hanifah melalui aspek sosial, dengan judul Akar-Akar Sosiologis Pemikiran Hukum Islam Abu Hanifah. Dalam hal ini penulis mengajak para pembaca untuk memasuki alam pemikiran hukum seorang ulama mazhab yang dipengaruhi oleh faktorfaktor sosio kultur di sekitarnya.

\section{Sketsa Biografi Imam Abu Hanifah}

Abu Hanifah juga dikenal dengan nama panggilan Imam Ḥanafi atau Abu $>$ Hani $>$ fah, memiliki nama lengkap al-Nu'ma $>\mathrm{n}$ bin Thabit bin Zuht. ${ }^{1}$ Ia lahir di kota Kufah-Irak pada tahun $80 \mathrm{H}$, dan meninggal di tahun 150 Hijriyah di kota Baghdad. ${ }^{2}$ Alasan di balik pemberian nama Abu Hanifah adalah karena ketaatannya dalam beribadah kepada Allah swt. Dalam nomenklatur bahasa Arab, nama $H\left\{a>\right.$ nif berarti "condong" atau "cenderung kepada yang benar". ${ }^{3}$ Menurut riwayat lain, disebutkan bahwa gelar Abu Hanifah itu disebabkan beliau sangat rajin belajar dan mendedikasikan hidupnya dalam dunia ilmu, dekat dan erat dengan "tinta", yang dalam bahasa Irak Hanifah berarti tinta. ${ }^{4}$

Abu Hanifah dilahirkan di lingkungan Islam yang taat dalam keberagamaanya. Hal ini dapat dilihat dalam beberapa referensi bahwa ketaatan di lingkungan keluarganya ialah ketika pada suatu saat ayahnya Thabit, bertemu dengan sahabat Ali bin Abi Thalib. Melalui momentum tersebut ia memanfaatkan pertemuan itu dengan meminta sahabat Ali untuk mendoakan agar keturunannya diberi kebaikan dan keberkahan. ${ }^{5}$ Thabit mengetahui betul bahwa sahabat Ali adalah salah seorang yang diberikan kelebihan-kelebihan oleh Allah untuk dekat dengan Nabi Muhammad, dan bahkan menjadi orang pilihan

\footnotetext{
${ }^{1}$ Dewan Redaksi Ensiklopedi Islam, Ensiklopedi Islam untuk Pelajar, Jilid 2 Jakarta: Ichtiar Baru van Hoeve, 2001), 83.

${ }^{2}$ Abd. Waha $>$ b Khalla $>$ f, Khula $>$ s $\} a b$ Ta $>$ rikh al-Tashri>' al-Isla $>m y$, Terj. A. Aziz Masyhuri (Solo: CV. Ramadhani, 1991), 83.

${ }^{3}$ Dewan Redaksi Ensiklopedi Islam, Ensiklopedi Islam, 83.

${ }^{4}$ M. Ali Hasan, Perbandingan Maz̧hab (Jakarta: PT. RajaGrafindo Persada, 1995), 184.

${ }^{5}$ Ahmad Al-Shurbashi, al-A'immah al-Arba'ah (Beirut: Dar Al-Hilal, t.t),18.
} 
nabi. Ia meyakini bahwa Ali mendapatkan kedudukan yang tinggi di hadapan nabi.

Berbagai versi tentang siapa Thabit, ayah Abu Hanifah. Pendapat yang dihimpun al-Shurbashi mengatakan bahwa satu versi ia keturunan Anbar, satu versi keturunan Turmudhi, satu versi ia keturunan Nasa'. ${ }^{6}$ Muhammad Abu Zahrah menambahi, bahwa Imam al-Khatib dalam buku Tarikh Baghdad menyatakan bahwa ia keturunan Babil (Babilonia), bahkan ada yang mengatakan keturunan Arab, ${ }^{7}$

Pada masa kecil Abu Hanifah, ia tinggal di salah satu rumah para pedagang, hal ini dikarenakan keluarganya adalah seorang pedagang. Oleh karena itu, semenjak kecil ia hidup di lingkungan dunia perdagangan. Bahkan beliau sendiri adalah seorang pedagang tekstil. Kecenderungan kepada dunia perdagangan ini barangkali pada akhirnya turut mempengaruhi perkembangan pikirannya yang rasional. ${ }^{8}$ Sebab ia akan selalu berhadapan dengan semua orang dengan karakter yang berbeda-beda.

Pada mulanya ia gemar belajar qira'at, hadis, nahwu, sastra, sya'ir, teologi, dan ilmu-ilmu lainnya yang berkembang pada masa itu. Namun di antara ilmu-ilmu yang sangat diminatinya adalah teologi, sehingga ia menjadi salah satu tokoh terpandang dalam ilmu tersebut. Sehingga karena ketajaman pemikirannyalah ia sanggup menangkis serangan golongan khawarij yang doktrin ajarannya sangat ekstrim. ${ }^{9}$

Beliau adalah seorang ulama yang sering disalahpahami, kadangkala dipuja secara berlebihan tetapi juga sering dihina melampaui batas. Orang-orang yang fanatik terhadap mazhab Hanafi mengklaim bahwa Abu Hanifah punya kedudukan yang hampir sama dengan Nabi dann Rasul. Namun di lain pihak, orang yang belum memahami jalan pikirannya menganggap bahwa Abu> Hani $>$ fah sebagai perusak agama, berfatwa tanpa dalil, zindiq, dan tidak jarang di vonis sebagai orang kafir. ${ }^{10}$

Hal tersebut terjadi karena beliau adalah seorang ulama yang mempunyai kecerdasan intelektual yang tinggi, pemahaman yang dalam, wara' dan takwa. Bahkan pada saat itu Abu Hanifah mendapatkan predikat al-Imam al-A'dram, karena keluasan ilmunya. ${ }^{11}$

Dalam sejarah dapat kita ketahui bahwa Abu Hanifah tidak mau terlibat dalam masalah pemerintahan. Hal ini terlihat ketika beliau ditunjuk sebagai

\footnotetext{
${ }^{6}$ Ahmad Al-Shurbashi, al-A'immah al-Arba'ah, 18.

${ }^{7}$ Muhammad Abu> Zahrah, Abu> H\{ani>fah, Hayatubu wa 'ashrubu (Mesir: Dar Fikr al-Arabi, t.th), 15.

8 Zarkowi Soeyoeti, Pengantar Ilmu Figh (Semarang: Walisongo Press, 1987), 113.

${ }^{9}$ Sam'ani, Metode Istinbat Hukum Islam Imam Abu Hanifah, Jurnal Hukum IslamVol. 1, No.

1, Oktober 2003, 53.

${ }^{10}$ Muhammad Abu> Zahrah, Abu> $H\{a n i>f a h, 7$.

${ }^{11}$ Mun'im A. Sirry, Sejarah Fiqih Islam: Sebuah Pengantar (Surabaya: Risalah Gusti, 1995), 83.
} 
hakim (qad\}i) pada masa pemerintahan Bani Umayyah (Gubernur Irak, Yazid bin Hubairah) dan Abbasiyah (Khalifah kedua dari Bani Abbas, Abu Ja'far alMansur). Ini dilakukan oleh beliau dengan alasan bahwa masa depan fiqh harus bebas dari kekangan penguasa. Sebab hanya dengan menghindari ikatan-ikatan kedudukan ia dapat leluasa mengembangkan kajian-kajian fiqhiyahnya. Itulah sebabnya Abu Hanifah memperjuangkan kebebasan berpendapat. ${ }^{12}$

Namun karena sikap penolakannya terhadap pemerintahan Abbasiyah inilah beliau meninggal dengan cara yang tragis. Abu Hanifah meninggal dengan cara dipenjara dan dicambuk, pada akhirnya beliau menghembuskan nafas terakhirnya pada tahun $150 \mathrm{H}$, karena penderitaan yang ditimpanya.

\section{Beberapa Kitab Fiqh Versi Hanafiyah}

Dalam mengkaji pemikiran hukum Abu Hanifah dan para pengikutnya, perlulah kita mengetahui dan mengkaji gagasan-gagasan mereka yang dituangkan dalam beberapa kitab. Sebagaimana mengutip pendapat Abu Zahrah yang menjelaskan bahwa Abu Hanifah tidak menulis kitab secara langsung kecuali beberapa risalah kecil yang dinisbahkan kepadanya. Seperti risalah yang dikenal dengan nama al-Figh al-Akbar dan al-'Alim wa al-Muta'alim. ${ }^{13}$ Risa>lah kepada 'Uthma>n, Risa>lah al-Radd 'ala $>$ al-Qadriyyah. ${ }^{14}$

Meskipun Abu Hanifah belum merumuskan pemikirannya tentang fiqh yang dibukukan dalam bentuk sebuah kitab, namun gaya pemikirannya yang tertulis dalam risalah-risalah kecil tersebut ternyata berhasil menggerakkan perubahan sehingga berjaya menyumbangkan penyelesaian persoalan-persoalan hukum yang berkembang pada masa itu.

Masalah-masalah fiqh yang terdapat dalam mazhab Hanafi dibedakan menjadi tiga, yaitu: al-Us\}u>l, al-Nawa $>$ dhir, dan al-Fatawa.

1. Al-Us $\} u>$ ladalah pendapat yang diriwayatkan oleh $\mathrm{Abu}>\mathrm{H}\{\mathrm{ani}>$ fah dan sahabatnya, seperti Abu Yusuf Ya'qu $>$ b ibn Ibra $>$ hi $>$ m Al-Ans $\} a>$ ry Al$\mathrm{Ku}>$ fy, Muhammad ibn Hasan al-Shaiba $>$ ni dan Zufar Ibn Hudhail ibn Qais Al-Ku>fy. Kemudian dikumpulkan pendapat-pendapat tersebut dan disusun oleh Muhammad ibn Hasan al-Shaiba>ni dalam kitab Zhabir alRiwayah. Kemudian yang termasuk dalam kitab tersebut adalah: alMabsu>t\}, al-Jami>' al-S\{a>ghi>r,al-Jami>’ al-Kabi>r, al-S\{iya $>r$ al$S\left\{a>g h i>r\right.$, al-S $\left\{\right.$ iya $>r$ al-Kabi $>r$, al-Ziya $>$ dat. ${ }^{15}$

\footnotetext{
${ }^{12}$ Mun'im A. Sirry, Sejarah Fiqih Islam: Sebuah Pengantar, 85.

${ }^{13}$ Jaih Mubarok, Sejarah dan Perkembangan Hukum Islam (Bandung: PT. Remaja Rosdakarya, 2000), 77.

${ }^{14}$ Muh ammad Abu> Zahrah, Ta>rikh al-Madha $>$ hib Isla $>$ miyyah wa Madha $>$ bib Fiqhiyyah. (Damsyi $>$ q: Da $>$ r al-Fikr, tt.), 170.

15 Teuku Muhammad Hasbi Ash-Shiddieqy, Pengantar Ilmu Fiqh (Jakarta: Bulan Bintang, 1991), 114.
} 
2. Al-Nawa $>$ dhir adalah pendapat-pendapat yang diriwayatkan dari Abu> $\mathrm{H}\{$ ani $>$ fah dan sahabatnya yang tidak terdapat dalam kitab Zhahir alRiwayah. Adapun kitab-kitab yang terkenal yang termasuk dalam alNawa>dhir adalah al-Kaisa>niyyah, al-Ruqayyah, al-Haru>niyyah, alJurja $>$ niyyat. ${ }^{16}$

3. Al-Fatawa adalah pendapat-pendapat para pengikut $\mathrm{Abu}>\mathrm{H}\{\mathrm{ani}>\mathrm{fah}$ yang tidak diriwayatkan oleh $\mathrm{Abu}>\mathrm{H}\{$ ani $>$ fah. Seperti: kitab al-Nawazil, kitab al-Fatawa al-Khaniyyat, al-Fatawa al-Hindiyyah, al-Fatawa al-Khairiyyah, al-Fatawa al-Bariyyah, al-Fatawa al-Hamidiyyah.

Selain kitab-kitab yang telah disebutkan di atas, terdapat pula kitab-kitab fatwa dan hasil-hasil ijtihad yang dilakukan oleh para mutaakhirin dari muridmurid Imam Abu Hanifah. Demikian juga sejumlah hadis dalam kitab Musnad karya Imam Hanafi yang diriwayatkan dari Ja'far Shadiq dan Muhammad al$\mathrm{Ba}>$ qir. Masih lagi beberapa hadis dalam kitab Musnad karya Abu Hanifah, alAtsar karya Imam Muhammad, dan al-Atsar karya Abu Yusuf. Selain kedekatannya dengan kedua tokoh tersebut, $\mathrm{Abu}>\mathrm{H}\{\mathrm{ani}>\mathrm{fah}$ berjuang melawan penguasa di zamannya bersama kalangan syi'ah, sehingga sebagian orang menuduh Abu Hanifah adalah periwayat hadis syi'ah, seperti alSyahristani. ${ }^{17}$

\section{Metode Istinbat Hukum Imam Abu Hanifah}

Sebagai ulama Abl al-Ra'yi, Abu Hanifah banyak menggunakan logika dalam menetapkan hukum. Ia mengutamakan ra'yu daripada khabar ahad. Apabila terdapat hadis yang bertentangan, ia menetapkan hukum dengan jalan qiya $>s$ dan istib\}sa $>n$. Maka untuk mengetahui lebih rinci bagaimana metode Abu Hanifah dalam menetapkan hukum, dapat diketahui dari ungkapannya:
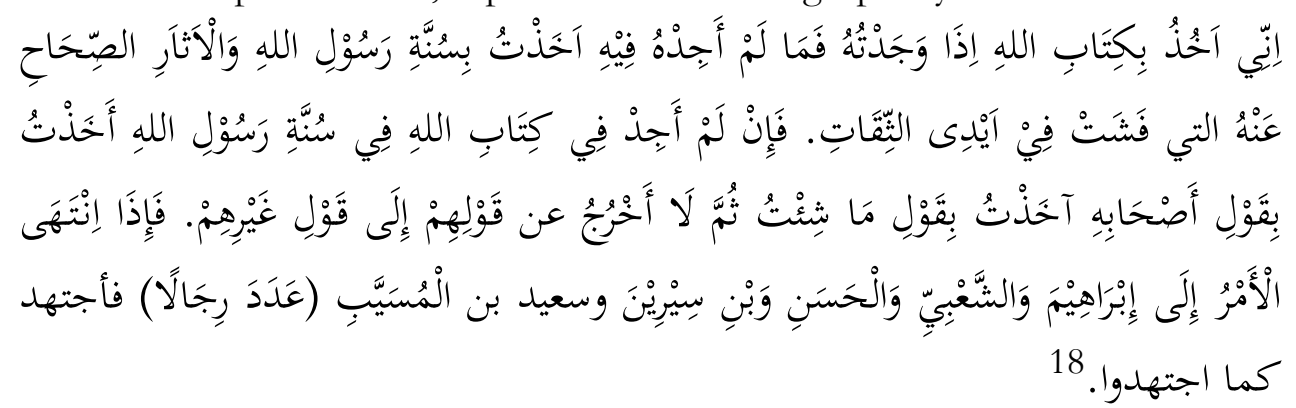

\footnotetext{
16 Jaih Mubarok, Sejarah dan Perkembangan Hukum Islam, 77.

17 Abd al-Karim Syahristani, al-Milal wa al-Nihal, (Beirut: Dar al-Ma'rifah, tt.), 222-223.

${ }^{18} \mathrm{Ahmad}$ ibn Ali Abu Bakar al-Khatib al-Baghdadi, Tari>kh Baghdad, (Beirut: Dar al-Kutub alAlamiyyah, 1990), Jilid XIV, 368.
} 
"Saya mengambil dari Kitabullah, jika tidak saya temukan dari al-Qur'an, saya mengambil dari Sunnah Rasulullah saw yang shabih dan yang terdapat dikalangan orang-orang yang bias dipercaya. Jika tidak saya temukan di dalam Kitabullah dan Sunnah Rasulullah saw, saya beralih kepada perkataan Sahabat, saya ambil yang saya butubkan dan saya tinggalkan yang tidak saya butubkan. Setelab berpijak kepada pendapat para sababat, saya menengok pendapat orang lain, jika telah sampai kepada pendapat Ibrabim, Sya'bi, alHasan, Ibnu Sirin dan Sa'id bin Musayyib (karena beliau menganggap mereka adalah mujtabid) maka saya akan berijtihad sebagaimana mereka berijtihad".

Dari keterangan di atas, dapat disimpulkan bahwa Abu Hanifah selalu menggunakan ra'yu apabila tidak menemukan dalil al-Qur'an atau hadis shahih. Ia sangat selektif dalam menerima hadis. Abu Hanifah memperhatikan muamalah manusia, adat istiadat, serta urf mereka. Oleh karena itu, alur metode istinbat\} hukum yang diterapkan oleh Imam Hanafi dapat digambarkan sebagai berikut:

Al-Qur'an $\rightarrow$ Hadis Shahih $\rightarrow$ Qaul Sababah $\rightarrow$ Ijma' $\rightarrow$ Qiya $>_{s} \rightarrow$
Istib $\{s a>n \rightarrow$ Urf
Mazhab Hanafi telah menggambarkan upaya penyesuaian hukum Islam (figh) dengan kebutuhan-kebutuhan masyarakat di segala bidang. Dari skema di atas dapat diketahui bahwa mazhab Hanafi membuat bidang-bidang ijtihad semakin luas. Hal ini membuat suatu ketentuan hukum dapat ditetapkan sesuai dengan keadaan masyarakat tanpa keluar dari prinsip-prinsip dan aturan pokok ajaran Islam. Hemat penulis, perlulah kiranya menjelaskan secara garis besar beberapa keterangan terkait dengan gambar alur isitinbat $\}$ hukum di atas. Hal ini ditujukan agar tercapai pengertian dan pemahaman tentang metode istinbat $\}$ tersebut.

\section{Qaul Sababah}

Para sahabat menurut Abu Hanifah adalah termasuk golongan orang-orang membantu menyampaikan risalah agama, mereka lama bergaul dan dekat dengan Rasulullah, sehingga mereka tahu bagaimana kaitan hadis Nabi dengan al-Qur'an.

Perkataan sahabat mendapat posisi yang kuat dalam pandangan beliau, karena menurutnya, mereka adalah pembawa ajaran Rasul sepeninggalnya. Dengan demikian, pengetahuan dan pernyataan keagamaan mereka lebih dekat dengan kebenaran. Oleh karena itu, pernyataan hukum mereka dapat dikutip dan dijadikan pedoman dalam kehidupan masyarakat. 19

2. Ijma'

Ijma' menurut bahasa Arab berarti kesepakatan atau sependapat tentang sesuatu hal. Menurut istilah ijma', ialah kesepakatan mujtahid ummat

${ }^{19}$ M. Ali Hasan, Perbandingan Maz̧ab, 189. 
Islam tentang hukum syara' dari peristiwa yang terjadi setelah Rasulullah SAW meninggal dunia.

Sebagai contoh ialah setelah Rasulullah SAW meninggal dunia diperlukan pengangkatan seorang pengganti beliau yang dinamakan khalifah. Maka kaum muslimin yang ada pada waktu itu sepakat untuk mengangkat seorang khalifah dan atas kesepakatan bersama pula diangkatlah Abu Bakar RA sebagai khalifah pertama. Sekalipun pada permulaannya ada yang kurang menyetujui pengangkatan Abu Bakar RA itu, namun kemudian semua kaum muslimin menyetujuinya. Kesepakatan yang seperti ini dapat dikatakan ijma'.

3. Qiya $>s$

Menurut para ulama ushul figh, ialah menetapkan hukum suatu kejadian atau peristiwa yang tidak ada dasar nashnya dengan cara membandingkannya kepada suatu kejadian atau peristiwa yang lain yang telah ditetapkan hukumnya berdasarkan nash karena ada persamaan illat antara kedua kejadian atau peristiwa itu. Telah terjadi suatu kejadian atau peristiwa yang perlu ditetapkan hukumnya, tetapi tidak ada nas yang dapat dijadikan dasar untuk menetapkannya.

4. Istib\}san

Secara etimologi istih $\}$ sa $>n$ adalah mengikuti sesuatu yang menurut analisis nalar adalah baik, secara fisik maupun nilai. Sedangkan secara terminologi arti kata istih $\} s a>n$ menurut mazhab Hanafi adalah berpaling dari satu hasil qiya $>s$ pada hasil qiya $>s$ yang lain yang lebih kuat. Metode ini merupakan bentuk penggunaan rasio dengan cara analogis ilmiah secara ketat dengan tujuan mencapai kemaslahatan yang lebih baik. ${ }^{20}$

5. Urf (kebiasaan).

Urf (adat kebiasaan) adalah segala sesuatu yang sudah dikenal diantara manusia dan telah dibiasakan oleh mereka serta dijalankan secara terus menerus baik berupa perkataan ataupun perbuatan. Adat kebiasaan yang dilakukan oleh masyarakat tersebut dapat digunakan sebagai hukum apabila tidak bertentangan dengan dalil syara.. ${ }^{21}$ Di antara contohnya adalah penggunaan kata walad sebagai anak baik laki-laki maupun perempuan, selain itu dalam hal jual beli cukup dengan serah terima barang dengan tanpa ucapan ijab kabul.

\section{Beberapa Contoh Pemikiran Abu Hanifah}

Di antara beberapa contoh pemikiran fiqh Abu Hanifah yang bercorak logis rasionalis ini dapat penulis gambarkan dalam beberapa fatwa hukum di bawah ini, yaitu:

\footnotetext{
20 Abbas Arfan, Geneologi Pluralitas Mą̧hab dalam Hukum Islam (Malang: UIN Malang Pers, 2008), 80.

${ }^{21}$ M. Ali Hasan, Perbandingan Mažbab, 194.
} 
1. Hakim di pengadilan dapat dipimpin oleh seorang perempuan, akan tetapi ketentuan ini hanya berlaku dalam ranah hukum perdata, seperti perkawinan, muamalah, waris, dan lain-lain. sedangkan untuk perkara pidana atau tindak kriminal, Abu Hanifah dengan tegas melarang perempuan menjadi hakim dalam pengadilan pidana. Hal ini dikarenakan perempuan tidak diperbolehkan menjadi saksi pidana, ia hanya dibenarkan menjadi saksi perkara perdata. Berdasarkan analogis ini, akhirnya ia berpandangan bahwa perempuan hanya boleh menjadi hakim dalam perkara-perkara perdata. Dengan demikian metode ijtihad yang digunakannya adalah qiya $>$ s, yang mana dengan menjadikan kesaksian sebagai al-As\}ldan menjadikan hakim sebagai far'.

2. Tidak najisnya hukum air yang dijilat oleh burung buas (elang/gagak). Menurut qiy $a>s$ jaliy, air tersebut najis hukumnya karena di-qiya $>$ s-kan dengan sisa air bekas minum binatang buas. Karena ada persamaan illat, yaitu dagingnya haram untuk dimakan, maka air liurnya pun dianggap tidak bersih.

Akan tetapi jika menggunakan (Istih\}sa>n) qiya $>$ s khafiy, maka hukum air bekas jilatan burung buas itu bersih. Ini dikarenakan pada kenyataannya burung buas minum air tidak dengan lidahnya, namun dengan paruhnya, sedangkan paruhnya tersebut bersih. Sehingga dapat disimpulkan bahwa air sisa minuman burung buas tidak najis karena burung itu disamakan dengan burung biasa yang halal jika memakannya.

3. Membaca al-Qur'an dalam $s$ alat dengan bahasa persi (selain bahasa arab) dinilai sah. Al-Sharkhasi dalam kitabnya menjelaskan:

"Menurut Imam Sya $>$ fi'i $>$ tidak boleh membaca al-Qur'a $>$ n dengan bahasa Parsi dalam berbagai keadaan, tetapi jika dia ummi (buta huruf), maka salat dengan cara diam. ${ }^{22}$ Sedangkan menurut Imam $\mathrm{Abu}>>\mathrm{H}\{$ ani $>$ fah, sesungguhnya qira'ah dengan bahasa Parsi itu seperti qira'ah dengan bahasa Arab, bahkan dapat memenuhi fardunya salat", sebab kemu’jizatan alQur'a $>n$ itu dari sudut makna. Selain itu peristiwa Salman al-Farisi, yang menulis surah al-Fatihah dengan bahasa Parsi kepada Bangsa Parsi, kemudian mereka membacanya dengan bahasa Parsi dalam s\}alat, Salman al-Farisi mengatakannya hingga engkau mampu berbahasa Arab. Adapun menurut Abu> $\mathrm{H}\{$ asan al-Syaibani $>$ dan Muh $\}$ ammad Abu> $\mathrm{Yu}>$ suf, bahasa Parsi tidak mewakili bahasa al-Qur'a $>$ n secara mutlak, kerana itu tidak dapat menggugurkan kewajiban bacaan al-Qur'a $>n$ untuk orang yang mengetahui bahasa Arab. Namun bagi orang yang tidak mampu berbahasa Arab maka bahasa Parsi dapat menggugurkan fardunya bacaan salat". Sedangkan menurut Imam Sya $>$ fi' $>>$ menolak pendapat keduanya, kerana

22 Abi> Bakr Muh\}ammad b. Ah\}mad b. Abi $>$ Sahal al-Sarakhsi>, Kita $>b$ al-Mabs\}u $>t\}$, Tab \}qi\}q Mub\}ammad H\}asan Isma> i>l, (Beirut: Da>r al-Kutub al-'Ilmiyyah, 2001), 37. 
bahasa Parsi itu bukan bahasa al-Qur'a $>$ n, maka yang wajib itu bacaan alQur'a $>n$ berbahasa Arab. Oleh itu bacaan bahasa Parsi tidak dapat menggugurkan kewajiban bacaan al-Qur'a $>n$, al-Qur'a $>n$ itu mu'jizat, sedangkan mu'jizat itu dari sisi al-niz\} $a>m$ wa al-makna (teks dan makna)." ${ }^{\prime 23}$

4. Dalam menghitung masa iddah, kebolehan seorang wanita menikah lagi adalah dengan tiga kali haid, bukan tiga kali suci. Hal tersebut bertujuan untuk mengetahui apakah rahim dalam kondisi terisi oleh janin atau tidak. Fatwa hukum tersebut merupakan hasil pemikirannya mengenai identifikasi lafaz\} musytarak dalam surat al-Baqarah ayat 228. Al-qur'u dalam ayat tersebut adalah lafaz\} musytarak yang memiliki banyak makna. Makna yang terpilih adalah makna yang yang didukung dengan dalil lain. Adapun Abu Hanifah menunjukan dalil naqli pendukung berupa hadith:

$$
\text { قا ل رسول الله صلي الله عليه وسلم لفاطمة بنت أبي حبيش : دعي الصلاة أيام أقرائك }
$$

"Rasulullah S.A.W. berkata kepada Fatimah binti Abi Hubaish: Tinggallah kamu melakukan shalat pada hari-hari haidmu", ${ }^{24}$

5. Nikah tanpa wali berhukum sah menurut Abu Hanifah selama kedua mempelai sekufu'. Hal ini didasarkan pada ayat yang berbunyi, "fala $>$ juna $>$ ha 'alaikum $f i>m a>$ fa'alna $>$ fi $>$ anfusibinna bi al-ma'ru $>f$ '. Adapun hadith $L a>$ nika $>$ ha ila $>$ bi waliyyin was ha> hiday 'adl merupakan hadith d\} aif..$^{25}$

\section{Faktor-faktor sosiologis Peubah Pemikiran Abu Hanifah}

Sebagaimana yang telah dikemukakan diatas, bahwa Abu Hanifah adalah termasuk dalam golongan $A b l$ al-Ra'yi. Konsep rasional ini dilakukan ketika suatu permasalahan tidak diketemukan dalam nas $\}$. Beliau mempunyai thariqul istinbat\} (jalan sendiri) dalam membahas hukum dan mempunyai kemampuan yang luar biasa dalam istinbat\}. Selain itu pula Abu Hanifah memiliki bekal keberanian dalam menghadapi persoalan-persoalan yang tumbuh.

Sangat menarik untuk diketahui lebih lanjut, bagaimana proses nalar akal yang mempengaruhi jalan pemikiran Abu Hanifah. Tentunya hal ini bukan sebuah rekayasa hukum yang dilakukan oleh beliau untuk suatu tujuan. Maka dari sini penulis mencoba untuk memaparkan faktor-faktor apa saja yang melatarbelakangi pemikiran imam Abu Hanifah yang banyak menggunakan akal, sebagai berikut:

1. Faktor Geografis dan Sosiologis

\footnotetext{
23 Ibid., 133.

${ }^{24}$ Imam al-Dar Qutni, Muhammad Ali al-Sabuni, Rawai' al-Bayan, (Beirut: Dar al-Fikr, 1995), 329.

${ }^{25}$ Ibnu Rushd, Bida $>$ yat al-Mujtahid, (Beirut: Da>r al-Fikr, tt.), 6.
} 
Abu Hanifah hidup di Kufah, Irak yang letaknya jauh dari kota Madinah tempat Nabi Muhammad hidup dahulu. Berikut ini perbandingan dari segi geografis:

\begin{tabular}{|l|l|l|}
\hline No. & Kufah & Madinah \\
\hline 1 & $\begin{array}{l}\text { Tidak banyak orang yang } \\
\text { mengetahui benar tentang } \\
\text { sunnah Nabi Muhammad }\end{array}$ & $\begin{array}{l}\text { Banyak orang yang mendengar } \\
\text { dan mengetahui Sunnah Nabi }\end{array}$ \\
\hline 2 & $\begin{array}{l}\text { Masyarakat Heterogen, dan } \\
\text { suasana kota terdiri dari } \\
\text { berbagai suku bangsa }\end{array}$ & $\begin{array}{l}\text { Penduduk dalam kategori } \\
\text { Homogen, dan hidup dalam } \\
\text { suasana Agraris }\end{array}$ \\
\hline 3 & $\begin{array}{l}\text { Intensitas penggunaan } \\
\text { Sunnah Nabi Muhammad } \\
\text { lebih sedikit, maka porsi } \\
\text { pendapat atau pemikiran } \\
\text { secara nalar lebih banyak }\end{array}$ & $\begin{array}{l}\text { Penggunaan Sunnah Nabi yang } \\
\text { banyak dilakukan dalam } \\
\text { penentuan hukum }\end{array}$ \\
\hline 4 & $\begin{array}{l}\text { Sumber penerimaan hadis } \\
\text { berasal dari fuqaha }\end{array}$ & $\begin{array}{l}\text { Sumber penerimaan hadis bisa } \\
\text { langsung dari nabi dan para } \\
\text { sahabat }\end{array}$ \\
\hline 5 & $\begin{array}{l}\text { Peradaban manusia tinggi, } \\
\text { maka muncul problematika } \\
\text { yang bervariasi }\end{array}$ & $\begin{array}{l}\text { Problematika-problematika } \\
\text { yang terjadi di Kufah belum } \\
\text { pernah ada di Madinah }\end{array}$ \\
\hline
\end{tabular}

Dari tabel di atas dapat disimpulkan bahwa perbedaan intensitas dalam penggunaan sumber hukum ini, menyebabkan perbedaan-perbedaan pendapat yang akhirnya menimbulkan aliran-aliran pemikiran fiqih Islam. Maka benar jika Imam Hanafi dan para pengikutnya dikatakan sebagai $A b l$ al-Ra'yi.

Sebagaimana diketahui bahwa Abu Hanifah hidup di zaman pemerintahan kerajaan Umawiyah dan pemerintahan Abbasiyyah. Ia lahir pada masa pemerintahan Abdullah bin Marwan, dan meninggal dunia pada masa khalifah Abu Ja'far al-Mansur. ${ }^{26}$

Kufah adalah sebuah kota di Iraq yang didirikan oleh khalifah Umar bin Khattab pada tahun $27 \mathrm{H}$, untuk pemukiman tentaranya. Pada dasarnya Iraq sebelum dikuasai Islam merupakan daerah yang mempunyai peradaban maju. Kota tersebut sudah memiliki sistim irigasi, membuat gula, tekstil yang mempunyai tipe masyarakat kota dengan kemajuan ekonomi dan pengetahuan teknologi. ${ }^{27}$

${ }^{26}$ Ahmad Syurbasyi, Sejarah dan Biografi Empat Imam Mą̧ab Cet. Ke-2 Jakarta: PT. Bumi Aksara, 1993), 13.

27 Tutik Hamidah, Pemikiran Hukum Imam Abu Hanifah; Sebuah Tinjauan Historis, Jurnal STAIN Malang, No. 6, Tahun 1999, 30. 
Dari segi agama dan kepercayaan sebelum datangnya Islam merupakan daerah tempat tumbuh dan berkembangnya bermacam-macam agama dan kepercayaan, seperti agama majusi, nasrani, yahudi, madzkiyah, manawiyah. Di samping itu berkembang pula usaha-usaha mempelajari filsafat yunani kuno, filsafat rumawi dan aliran helenisme. ${ }^{28}$

Tutik menambahkan bahwa agama Islam bisa berkembang disana dan bahkan menstimulasi kemajuan peradaban ke tingkat puncak dan menjadikannya kota metropolis yang spektakuler serta menggeser semua agama dan kepercayaan yang lain. Pengaruh agama Islam semakin hari semakin nampak, ini terbukti dari terlihatnya kegiatan-kegiatan mempelajari agama Islam dan ilmu pengetahuan saja. ${ }^{29}$ Begitu pula terdapat kegiatan diskusi, tukar pendapat dan sebagainya yang diadakan di tempat-tempat tertentu.

Mazhab ini dianut sekarang di Turki, Syria, Irak, Afganistan, Pakistan, India, Cina, dan Uni Soviet. Di beberapa negara Islam, seperti Syria, Libanon dan Mesir, mazhab Hanafi menjadi mazhab hukum resmi. Sumber hukum yang mereka pergunakan adalah al-Qur'an, Sunnah dan Ra'yu, Ijma> ', Qiya $>$ s, Istib\}san serta Urf (adat kebiasaan) yang baik masyarakat setempat sebagai metode menemukan hukum. ${ }^{30}$

Farouq Abu Zaid menyebut beberapa faktor lain yang melatarbelakangi kecenderungan dan metode rasional Imam Abu Hanifah. Menurutnya penduduk Kufah merupakan masyarakat yang sudah banyak mengenal kebudayaan dan peradaban. Fuqaha di daerah ini sering dihadapkan dengan berbagai berikut problematikanya yang beraneka ragam. Maka dari itu, untuk mengatasi persoalan-persoalan tersebut mereka terpaksa menggunakan ijtihad dan akal. ${ }^{31}$

\section{Faktor Intelektualitas}

Sebagaimana telah disinggung di atas bahwa Abu Hanifah adalah tokoh rasionalis dalam maddhab fiqh. Dalam arti beliau menggunakan rasio dalam taraf yang optimal untuk menetapkan hukum. Beliau tidak menerima ajaran Islam sebagai dogma, akan tetapi sebagai suatu ajaran yang mempunyai tujuan, cita-cita ideal, harapan serta prinsip-prinsip dasar.

Lebih lanjut Farouq menambahkan, yang menyebabkan Abu Hanifah menjadi tokoh mujtahid rasionalis adalah beliau tidak hanya

28 Tutik Hamidah, Pemikiran Hukum Imam Abu Hanifah; Sebuah Tinjauan Historis, 30, sebagaimana mengutip Ahmad Amin dalam Fajr al-Islam (Maktabah al-Nahd\}at al-Misriyah, t.th.)

${ }^{29}$ Tutik Hamidah, Pemikiran Hukum Imam Abu Hanifah; Sebuah Tinjauan Historis, 31.

${ }^{30}$ Mohammad Daud Ali, Hukum Islam: Pengantar Ilmu Hukum dan Tata Hukum Islam di Indonesia (Jakarta: PT. RajaGrafindo Persada, 2005), 186.

${ }^{31}$ Farouq Abu Zaid, Hukum Islam, antara Tradisionalis dan Modernis (Jakarta: P3M, t.th), 10. 
berkecimpung dalam ilmu-ilmu syari'ah. $\mathrm{Abu}>\mathrm{H}\{$ ani $>$ fah juga mempelajari ilmu kalam pada awal karirnya, lalu berlanjut belajar fiqh di madrasah Kufah kepada Syeikh Hammad bin Sulaiman. ${ }^{32}$ Selain belajar fiqh dan hadis di Kufah, Abu> $\mathrm{H}\{$ ani $>$ fah beberapa kali pergi ke Hijaz untuk mendalami lagi fiqh dan hadis.

Abu Hanifah, akhirnya mencoba untuk mendalami berbagai ilmu pada beberapa guru, diantaranya Hammad ibnu Abi Sulaiman al-Ash'ari, Zaid ibnu Ali Ibnu Zainal Abidin, Muhammad al-Baqir Zainal Abidin, Ja'far al-Shadiq, Abdullah ibnu al-Hasan Ibnu al-Hasan, Jabir Ibnu Yazid al-Ju'fi, Ibrahim al-Nakha'i, Imam al-Shu'abi, dll. Sekalipun ia banyak belajar pada ulama', namun yang paling berpengaruh dalam pemikirannya adalah Hammad ibnu Abi Sulaiman al-Ash'ari seorang ahli figh daerah kufah, karena lamanya ia belajar padanya sekitar 40 tahun, sejak usianya 22 tahun. Ia belajar fiqh dan hadis pada imam Hammad, sekalipun di waktu bersamaan ia juga belajar figh pada Ibrahim al-Nakha'i dan Imam al-Shu'abi. ${ }^{33}$

Oleh karena Abu Hanifah belajar kepada imam Hammad dalam jangka waktu yang cukup lama, maka benar jika disimpulkan bahwa beliau banyak mempengaruhi alur pemikiran $\mathrm{Abu}>\mathrm{H}\{a n i>$ fah. Sedangkan imam Hammad sendiri dilihat dari susunan guru dan murid, adalah sampai kepada khalifah Umar bin Khat $\} \mathrm{t}\} \mathrm{a}>\mathrm{b}$ yang jalan pikirannya berpedoman kepada ra'yu dalam memahami nash. Dengan demikian, salah satu faktor yang mempengaruhi Abu Hanifah adalah salah satu aliran gurunya. ${ }^{34}$

Sepeninggal Syeikh Hammad bin Sulaiman, majelis Madrasah Kufah sepakat untuk mengangkat Abu Hanifah sebagai kepala madrasah. Selama itu, beliau mengabdi dan banyak mengeluarkan fatwa dalam masalah fiqh. Dalam sejarah ada yang menyatakan Abu Hanifah mempelajari ilmu fiqh dari Ibrahim, Umar, Ali bin Abi T \}alib, Abdullah bin Mas'ud dan Abdullah bin Abbas. $^{35}$

32 Ibid.

${ }^{33} \mathrm{Ah}$ \} mad al-Shurbashi, al-A'Immah al-Arba'ah, 22.

${ }^{34}$ Sebagaimana diketahui bahwa sosok Umar bin Khattab adalah salah seorang sahabat nabi yang revolusioner, mujtahid ulung dan seorang khalifah yang terkenal tegas dalam kehidupannya. Sifat-sifat tersebut dapat dilihat dalam fatwa-fatwanya ketika menjadi seorang khalifah di tanah Arab. Di mana ia banyak melakukan penafsiran-penafsiran ulang terhadap alQura'n dan kemudian disinkronkan dengan kehidupan saat itu. Oleh karena itu, tak jarang fatwafatwanya dianggap oleh sebagian pihak sebagai keputusan hukum yang kontreoversial, dan bahkan dicap telah keluar dari koridor syariat Islam. Namun inti dari keputusannya tersebut adalah menggali unsur-unsur maslahah yang terkandung dalam teks al-Qur'an, ia tidak mematenkan hukum hanya pada teks akan tetapi juga dilihat dari sisi-sisi kontektualitasnya. Baca Fahmi Assulthoni, "Progresivitas Pemikiran Hukum Umar bin Khattab " Ulumuna, Vol.1, No.1, Juni 2015, ISSN 2442-8566, (http://ejournal.kopertais4.or.id/madura/index.php/ulumuna/article/view/145), 127.

35 Ahmad Syurbasyi, Sejarah dan Biografi,....17. 


\section{Faktor Profesi}

Seperti yang kita kenal bahwa Abu Hanifah adalah seorang pedagang kain dan ia pula seorang yang sangat wara'. Beliau bergumul dalam bidang ini sudah semenjak ia kecil, karena keluarganya sendiri adalah pedagang. Dalam hidupnya penuh dengan berbagai macam cara hidup di masyarakat dan sebab dari perdagangan itu beliau juga sebagai sendi penghubung antara hidup dalam keluarga maupun agama. ${ }^{36}$

Terjunnya Abu Hanifah di dunia bisnis adalah sesuatu hal yang wajar akibat pengaruh dari kehidupan orang tuanya yang juga berprofesi sebagai pedagang. Adalah sebuah tradisi bahwa anak dari seorang pedagang akan meneruskan kiprah orang tuanya di dunia tersebut. Selain itu, pemenuhan kebutuhan hidup merupakan sebuah keniscayaan bagi setiap orang. Berdagang dianggap sebagai metode dan cara yang efektif untuk mengarungi kehidupan di dunia, dan bahkan berfungsi untuk mensyiarkan Islam ke semua manusia di muka bumi. Oleh karena, Abu Hanifah seorang pedagang, maka ia setiap hari disibukan dengan urusan dagang dan menghadapi masyarakat luas. Dari sana ia kemudian berusaha untuk menyelami kemaslahatan-kemaslahatan yang diinginkan manusia, karena itu pula beliau menjadikan Urf sebagai ajaran sumber hukum Islam dalam menghadapi sesuatu yang tidak diperoleh nas $\}$ nya. ${ }^{37}$ Konsekuensi logis atas kehidupannya sebagai ulama' yang berlatar-belakang pedagang adalah bahwa ia akan lebih banyak berfatwa hukum mengenai dunia perdagangan dan interaksi sosial.

4. Faktor Kondisi Perpolitikan dan Kecenderungan Pemikiran Pribadi

Abu Hanifah lahir bertepatan dengan masa pemerintahan yang dipimpin oleh dinasti Umayyah, yang saat itu dikomandoi oleh seorang khalifah bernama Abdul Malik bin Marwan. Ia juga merasakan masa transisi kepemerintahan dari dinasti Umayyah menuju era kebangkitan dunia Islam, yakni dinasti Abbasiyah. Pada masa dinasti Abbasiyah ini pucuk pimpiman pemerintah dipegang oleh Abu Ja'far al-Mansur dan menjadikan Islam pada saat itu sebagai pusat peradaban Islam dunia. ${ }^{38} \mathrm{Jika}$ Abu hanifah lahir pada tahun $80 \mathrm{H} / 699 \mathrm{M}$ dan wafat pada tahun $150 \mathrm{H}$., maka usia Abu Hanifah genap 70 Tahun, dan selama 52 tahun ia hidup di zaman dinasti umawiyah dan 18 tahun ia hidup di zaman dinasti Abbasiyyah.

Berdasarkan catatan sejarah, dinasti Umayyah mulai didirikan sejak tahun 41 Hijriah atau bertepatan dengan tahun 660 Masehi. Khalifah pertama yang menjadi pimpinan pada saat itu adalah Mu'awiyah bin Abi Sufyan yang menggantikan khalifah Ali bin Abi Thalib. Sebagaimana diketahui,

\footnotetext{
36 Ahmad Syurbasyi, Sejarah dan Biografi,....33.

37 T.M. Hasbi al-Shiddieqy, Falsafah Hukum Islam (Jakarta: Bulan Bintang, 1975), 60.

${ }^{38}$ Hasbi al-Shiddieqy, Falsafab Hukum Islam,.... 230.
} 
Mu'awiyah adalah sosok yang menginisiasi sebuah pergerakan untuk menumbangkan Ali sebagai khalifah yang sah. Ia lantang dan berani menentang dengan keras pemerintahan Ali dengan dalih bahwa kasus terbunuhnya khalifah Usman bin Affan r.a. belum diputus dengan seadiladilnya. Mu'awiyah menilai Ali memiliki hubungan dengan para pelaku pembunuh Usman, sehingga Ali dituduh sedang menyelamatkan pelakunya tersebut dari hukuman pidana. Akhirnya, pada tahun 37 Hijriah terjadilah gencatan senjata antara kubu Mu'awiyah dan kubu Ali dan dinamakan dengan perang Siffin.

Perang saudara antara Ali dan Muawiyah ini sejatinya terjadi sebanyak dua kali, yakni perang pertama adalah perang Siffin, dan kedua adalah perang Jamal. Pada perang kedua inilah, peperangan demi peperangan berangsur berakhir dengan proses tabkim (arbitrase). Akan tetapi proses damai ini menjadi cikal bakal munculnya perbedaan pandangan di antara umat muslim, yakni dengan keluarnya beberapa partisipan Ali dan ia mengasingkan diri dari dua kubu yang sedang bertikai tersebut, pada akhirnya aliran ini dikenal dengan aliran Khawarij. ${ }^{39}$ Saat itulah awal mula terjadinya pergolakan pemikiran dalam Islam sebagai pembenaran kelompok masing-masing, dengan munculnya 3 kelompok Islam pertama, yakni Syi'ah, Khawarij dan kelompok Mu'awiyah.

Khilafah Amawiyah yang pada saat itu terpusat di Iraq telah menimbulkan fanatisme kelompok, berbagai gerakan dan pemberontakan akibat otoriterisme pemerintahan. Bahkan pada saat khalifah Abd al-Malik Ibn al-Marwan, kondisi panasnya suhu politik belum dapat diredam. Akibat sikap yang apatis terhadap perkembangan pemikiran Islam, maka kelompok orang-orang alim dan cendekiawan mengambil posisi di luar pemerintahan. ${ }^{40}$ Golongan mawali termasuk di dalamnya, dan Abu Hanifah masuk dalam golongan mawali. Dan melalui jalur non formal, pemikiran Abu Hanifah memasyarakat sangat kuat. Hal ini menjadi embrio penggunaan mazhab Hanafiyyah sebagai mazhab resmi Negara pada periode Abbasiyyah. ${ }^{41} \mathrm{Hal}$ ini kemudian berpengaruh pada mazhab Syafi'i yang sulit diterima masyarakat luas kala itu di daerah Iraq sehingga ia dinilai lari dari keadaan itu menuju Mesir.

Dan ketika dinasti umawiyah jatuh, berganti dengan dinasti abasiyah, arus pemikiran meluas hingga taraf pemikiran filsafat yunani. Disamping pengaruh pemikiran filsafat, dan budaya diluar Arab, juga merupakan akibat

\footnotetext{
${ }^{39}$ Hasan Ibrahim, Sejarah dan Kebudayaan Islam Jilid I, (Jakarta: Kalam Mulia, 2006), 510.

${ }^{40}$ Liebesny H.J., The Law of The Near and Middle East: Reading, Cases, materials, (New York: State University of New York Prees Albany, 1975), 19.

${ }^{41}$ Manna>' al-Qat\}t $\} \mathrm{a}>\mathrm{n}$, Ta $>$ rikh al-Tasyri>' al-Isla $>$ mi>, (Kairo: Maktabah Wahbah, 1989), 325.
} 
logis dari letak geografis daratan Iraq (Baghdad, Kufah, Bahsrah) yang jauh dari pusat ilmu Islam (mekah dan Madinah), lahirlah dua metode pemikiran: a. Metode naql atau disebut ahli hadith yang menitikberatkan pada teks alqur'an dan hadith.

b. Metode 'aql, atau disebut ahli ra'yu yang menitikberatkan penggunaan aqal dalam menentukan hukum dengan berpedoman pada nash.

Namun mayoritas ulama' di daratan Iraq menjatuhkan pilihannya terhadap metode 'aql / ra'yu sebagai sarana penyelesaian hukum Islam yang mampu menjawab perkembangan zaman. Logis jika kondisi inilah menjadi salah satu pembentuk pola pemikiran Abu Hanifah yang mengedepankan ra'yu. $^{42}$

Abu Hanifah merupakan orang yang menjauh dari pemerintahan di zamannya. Bahkan pernah pada suatu saat khalifah marwan memintanya untuk menjadi seorang qadli/hakim, namun ia menolaknya, sehingga berakibat ia dihukum. ${ }^{43}$ Sampai pada akhirnya diketahui bahwa beliau meninggal dalam penjara oleh karena komitmenya yang begitu tinggi yang ia pegang.

\section{KESIMPULAN}

Mazhab Hanafi dibangun oleh Imam al-A'₹\}a>m Abu Hanifah, alNu'man bin Thabit bin Zuht. Dilahirkan pada tahun $80 \mathrm{H}$ dan telah meninggal dunia pada tahun $150 \mathrm{H}$. Beliau adalah seorang ulama mujtahid yang dikenal dengan pemikiran-pemikirannya yang banyak menggunakan nalar akal. Maka tak ayal jika beliau dianggap telah membuat hukum baru karena konsep ijtihad dirinya sendiri.

Corak pola pikir Abu Hanifah lebih bersifat logis, hal ini dikarenakan beliau banyak belajar fiqh pada ulama' Irak, dan beliau dianggap representatif untuk mewakili pemikiran aliran ra'yu. Selain itu faktor yang mempengaruhi pemikiran Imam Hanafi adalah kegiatan berdagang yang menuntut untuk berinteraksi sosial, dan harus ada ketetapan hukum jika terjadi problematika. Begitu pula faktor geografis yang mana kondisi Kufah berbeda jauh dengan di Madinah, baik dari segi peradaban maupun kultur masyarakat.

Dalam menetapkan hukum Islam, Abu Hanifah selalu berpegang teguh pada nash al-Qur'an, hadis, qoul sahabat dan ijma'. Namun jika tidak ditemukan di dalam ketiga sumber hukum tersebut, Abu Hanifah menggunakan ra'yu, yakni pengkomunikasian antara subtansi kandungan nash, mashalahat umum dengan fakta empiris masyarakat, sehingga qiya $>\mathrm{s}$, istih $\} s a>n$ dan 'urf merupakan dasar hukum yang juga dipegangi oleh beliau.

\footnotetext{
${ }^{42} \mathrm{Ahmad}$ Al-Shirbashi, Al-A'immah al-Arba'ah, 16-17.

${ }^{43}$ Khudlori Bik, Tarih al-Tasyri', 230.
} 
Akar-Akar Sosiologis Pemikiran Hukum Islam Abu Hanifah 


\section{DAFTAR RUJUKAN}

Abu $>$ Zahrah, Muhammad. Abu> H\{ani>fah Hayatubu wa 'ashrubu. Mesir: Dar Fikr al-Arabi, t.th - Ta>rikh al-Madha $>$ bib Isla>miyyah wa Madha $>$ bib Fiqhiyyah. Damsyi $>$ q: Da $>$ r al-Fikr, t.th.

Abu Zaid, Farouq. Hukum Islam, antara Tradisionalis dan Modernis. Jakarta: P3M, t.th.

A. Sirry, Mun'im. Sejarah Fiqih Islam: Sebuah Pengantar. Surabaya: Risalah Gusti, 1995.

Arfan, Abbas. Geneologi Pluralitas Mą̧ab dalam Hukum Islam. Malang: UIN Malang Pers, 2008.

Baghdadi (al), Ahmad ibn Ali Abu Bakar al-Khatib. Tarikh Baghdad, Jilid XIV. Beirut: Dar al-Kutub al-Alamiyyah, 1990.

Daud Ali, Mohammad. Hukum Islam: Pengantar Ilmu Hukum dan Tata Hukum Islam di Indonesia. Jakarta: PT. RajaGrafindo Persada, 2005.

Fahmi Assulthoni, "Progresivitas Pemikiran Hukum Umar bin Khattab" Ulumuna, Vol.1, No.1, Juni 2015, ISSN 2442-8566, (http://ejournal.kopertais4.or.id/madura/index.php/ulumuna/article/v iew/145)

Hasan, M. Ali. Perbandingan Mą̧ab. Jakarta: PT. RajaGrafindo Persada, 1995.

Khalla $>$ f, Abd. Waha>b. Khula $>$ s $\}$ ab Ta $>$ rikh al-Tashri>' al-Isla $>m y$, Terj. A. Aziz Masyhuri. Solo: CV. Ramadhani, 1991.

Mubarok, Jaih. Sejarah dan Perkembangan Hukum Islam. Bandung: PT. Remaja Rosdakarya, 2000.

Sam'ani. Metode Istinba>t\} Hukum Islam Imam Abu Hanifah, Jurnal Hukum IslamVol. 1, No. 1, Oktober 2003.

Syahristani, Abd al-Karim. al-Milal wa al-Nabl. Beirut: Dar al-Ma'rifah, t.th.

Syurbasyi, Ahmad. Sejarah dan Biografi Empat Imam Maz̧hab Cet. Ke-2. Jakarta: PT. Bumi Aksara, 1993.

Shurbashi (al), Ah\}mad. al-A'Immah al-Arba'ah. Beirut: Dar al-Hilal. t.th.

Shiddieqy (al), Teuku Muhammad Hasbi. Falsafah Hukum Islam. Jakarta: Bulan Bintang, 1975.

Shiddieqy (al), Teuku Muhammad Hasbi. Pengantar Ilmu Fiqh. Jakarta: Bulan Bintang, 1991. 
Soeyoeti, Zarkowi. Pengantar Imu Fiqh. Semarang: Walisongo Press, 1987.

Hamidah, Tutik. Pemikiran Hukum Imam Abu Hanifah; Sebuah Tinjauan Historis, Jurnal STAIN Malang, No. 6, Tahun 1999.

Dewan Redaksi Ensiklopedi Islam. Ensiklopedi Islam untuk Pelajar, Jilid 2. Jakarta: Ichtiar Baru van Hoeve, 2001. 